\title{
Strobilanthes reptans (Acanthaceae): a new addition to the flora of India
}

\author{
Sarma J. ${ }^{1}$, Barbhuiya H.A. ${ }^{2 *}$, Dey S. ${ }^{3}$ \& C.K. Salunkhe ${ }^{2}$ \\ ${ }^{1}$ Conservator of Forests, Northern Assam Circle, Assam Forest Department, Tezpur, Sonitpur, Assam - 784001 , India \\ ${ }^{2}$ Landscape and Cosmetic Maintenance Section, Architectural and Structural Engineering Division, \\ Bhabha Atomic Research Centre, Mumbai, Maharashtra - 400 085, India \\ ${ }^{3}$ Department of Botany, Nagaland University, Lumami, Nagaland - 798 627, India \\ ${ }^{\star}$ E-mail: hahmed@barc.gov.in
}

\begin{abstract}
Strobilanthes reptans (G.Forst.) Moylan ex Y.F.Deng \& J.R.I.Wood is reported here for the first time from India. A brief description of the plant along with a photo plate and distribution map is provided to facilitate its future identification. Its taxonomic affinities and differences with closely related species are examined and discussed.
\end{abstract}

Keywords: Arunachal Pradesh, Flora of India, Naturalization, New record, Strobilanthes.

\section{Introduction}

Strobilanthes Blume is the second largest genus of family Acanthaceae after Justicia L. (Wood \& Scotland, 2009), comprising about 448 species (POWO, 2019). It is distributed throughout tropical Asia (Hu et al., 2011). In India, the genus is represented by about 150 species (Karthikeyan et al., 2009; Thomas et al., 2020).

During a field exploration in July 2019 in the Tippi region of the West Kameng district of Arunachal Pradesh, the first author came across a Strobilanthes species. The plant was brought into cultivation, in order to study its floral morphology. Critical examination of flowering material revealed its identity as Strobilanthes reptans (G.Forst.) Moylan ex Y.F.Deng \& J.R.I.Wood, a species native to Southeast Asia and Australia. Screening of the relevant literature (Kanjilal et al., 1939; Venu, 2006;

Received: 16.09.2020; Revised \& Accepted: 12.05.2021

Published Online: 30.06 .2021
Chowdhery et al., 2008; Karthikeyan et al., 2009) further confirmed that this plant had not been reported from India. Hence, the present collection of the species not only forms a new addition to the flora of India, but also extends its distributional range up to the foothills of eastern Himalaya. A brief description of the plant along with a photo plate and distribution map is provided.

\section{Taxonomic Treatment}

Strobilanthes reptans (G.Forst.) Moylan ex Y.F.Deng \& J.R.I.Wood, Fl. China. 19: 390. 2011. Ruellia reptans G.Forst., Fl. Ins. Austr. 44. 1786. Hemigraphis reptans (G.Forst.) T.Anderson ex Hemsl., Rep. Voy. Challenger, Bot. 1(3): 173. 1885. Lectotype (designated by Moylan et al., 2002): VANUATU, Tana Island, G. Forster 148/242 (BM [BM000810986 digital image!]).

Ruellia primulifolia Nees, Prodr. 11: 144. 1847. Hemigraphis primulifolia (Nees) Fern.-Vill., Nov. App. 153. 1880. Strobilanthes primulifolia (Nees) Y.F.Deng \& J.R.I.Wood, J. Trop. Subtrop. Bot. 18: 483. 2010. Lectotype (designated by Moylan et al., 2002): PHILIPPINES, Sorsogon, T.P.X. Haenke s.n. (PR).

Hemigraphis pacifica Hosok., Trans. Nat. Hist. Soc. Formosa 25: 127. 1935. After 1935.Type: MELANESIA, Palau Islands, T. Hosokawa 7400 (holo, TAI)

Fig. 1

Herbs up to $20 \mathrm{~cm}$ tall. Stems short, erect, with shallow ridges, densely covered with multicellular trichomes. Leaves basal, opposite, isophyllous; lamina 


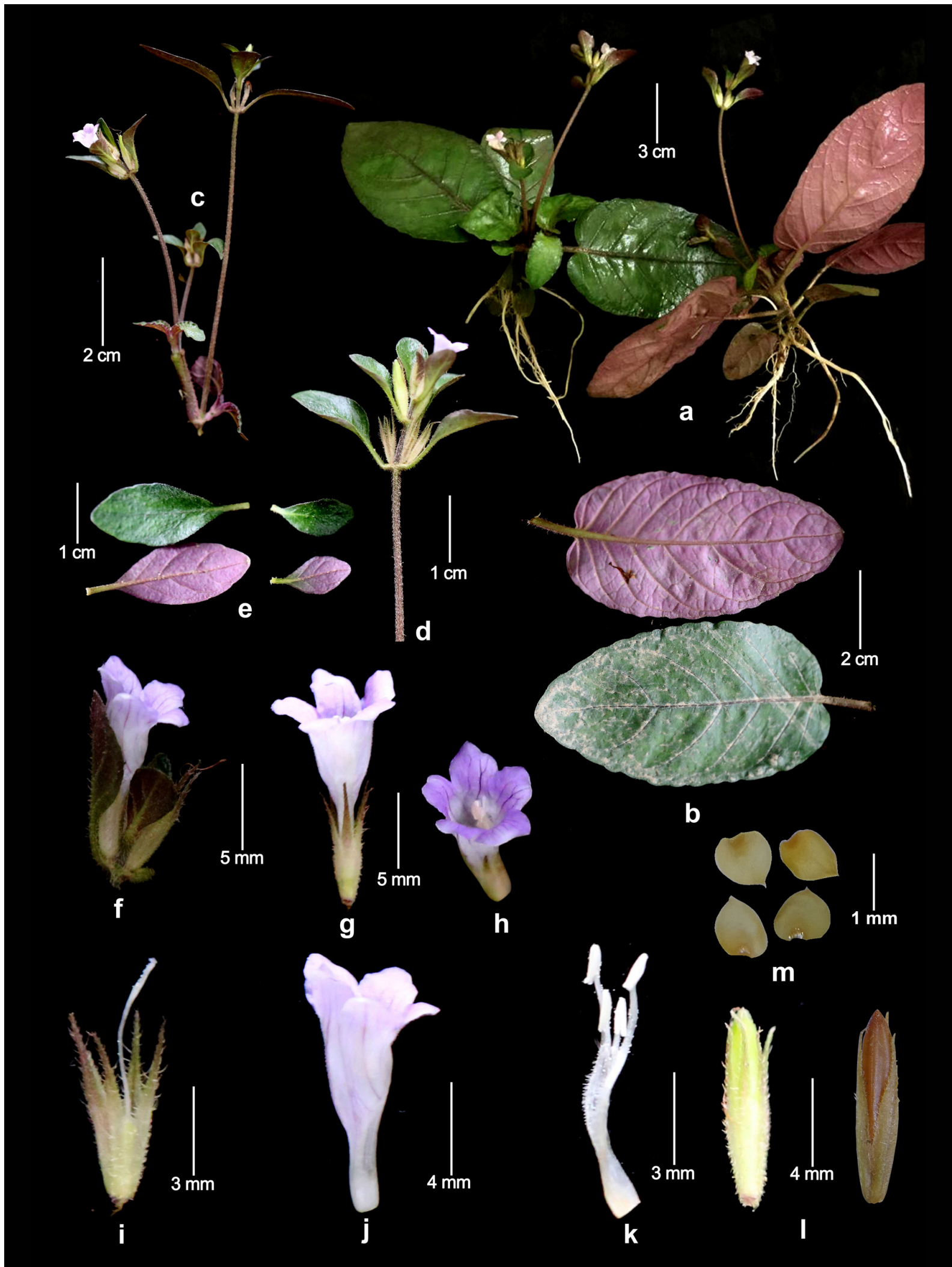

Fig.1. Strobilanthes reptans (G.Forst.) Moylan ex Y.F.Deng \& J.R.I.Wood: a. Habit; b. Dorsal and ventral surface of leaves; c. Inflorescence; d. Close-up of inflorescence; e. Bracts; f. Flower with bracts; g. Flower-side view; h. Flower-oblique top view; i. Calyx with gynoecium; j. Corolla-side view; k. Androecium; I. Immature (left) and mature (right) capsules with calyx; m. Seeds (from J. Sarma s.n.; photos by J. Sarma \& H.A. Barbhuiya). 
oblong-ovate or elliptic, $1-6 \times 0.6-3.5 \mathrm{~cm}$, adaxially dark green, sparsely pubescent, ventrally light pink, densely pubescent with multicellular trichomes especially along the midrib and lateral veins, margins sub-entire to repand or shallowly crenate, apex obtuse or obtusely acuminate, base subcordate; lateral veins 3-7 pairs, raised beneath; petioles $0.5-2.6 \mathrm{~cm}$ long, pubescent. Spikes terminal on main stems and from axils of upper leaves, elongating at maturity; peduncles $2-7 \mathrm{~cm}$ long, pubescent; bracts oblanceolate to elliptic, foliaceous, 1.3-2.7 × 0.6-1 cm, pubescent, margins entire, persistent. Calyx 5-lobed, 6.5-7.7 mm long, pubescent; lobes linear-lanceolate, 3.4-4.6 × 0.3$0.5 \mathrm{~mm}$, divided to the middle, margins ciliate. Corolla slightly 2-lipped, $1.1-1.2 \mathrm{~cm}$ long, white or pale violet with darker veins, glabrous; tube funnel-shaped, slightly ventricose, $8.8-9.1 \mathrm{~mm}$ long, base 1.1-1.3 mm in diam., mouth 3.5-4.1 mm wide; lobes sub-orbicular, 2.1-2.8 $\mathrm{mm}$ in diam. Stamens 4, included, didynamous; filaments united at base, pubescent, shorter pair with $0.5-0.8 \mathrm{~mm}$ free part, longer pair with $2.2-2.5 \mathrm{~mm}$ free part; anthers oblong, $1.2-1.5 \times 0.4-0.5 \mathrm{~mm}, 2$-thecous, sub-basifixed. Ovary oblong, c. $2.8 \mathrm{~mm}$ long; style filiform, c. $5.7 \mathrm{~mm}$ long, sparsely pubescent.
Capsules oblong, 8-9 mm long, 1.4-1.5 $\mathrm{mm}$ in diam., pubescent at apex. Seeds flat, ovate-orbicular in outline, $0.9-1.1 \times 0.8-0.9 \mathrm{~mm}$, apex acute.

Flowering \& fruiting: Flowering from June to September and fruiting from July to December.

Habitat: The plants grow on grassy hill slopes at an elevation of c. $180 \mathrm{~m}$.

Distribution: Taiwan, Japan (Ryukyu Islands), Singapore, Indonesia (Borneo, Seram, Sulawesi, Java, Moluccas, Talaud Islands, Irian Jaya), Philippines (Bohol, Guimaras Island, Leyte, Luzon and Samar), northern Australia, Melanesia (Palau Islands, Marshall Islands and Solomon Islands), New Caledonia (Loyalty Islands), Papua New Guinea (Bismarck Islands). Possibly escaped from cultivation and naturalized in India, Myanmar, Thailand, Laos, Vietnam, Malaysia, Sri Lanka, La Réunion, Hawaii, French Polynesia, and other parts of world (Fig. 2).

Specimen examined: INDIA, Arunachal Pradesh, West Kameng district, Tippi, N $27^{\circ} 02^{\prime} 04.58^{\prime \prime}, \mathrm{E}$ 92³6'22.93", 06.07.2019, J. Sarma s.n. (HBARC [HBARC00006506]).

Notes: Strobilanthes reptans shows close affinity with S. hirta (Vahl) Blume [= Hemigraphis hirta (Vahl)

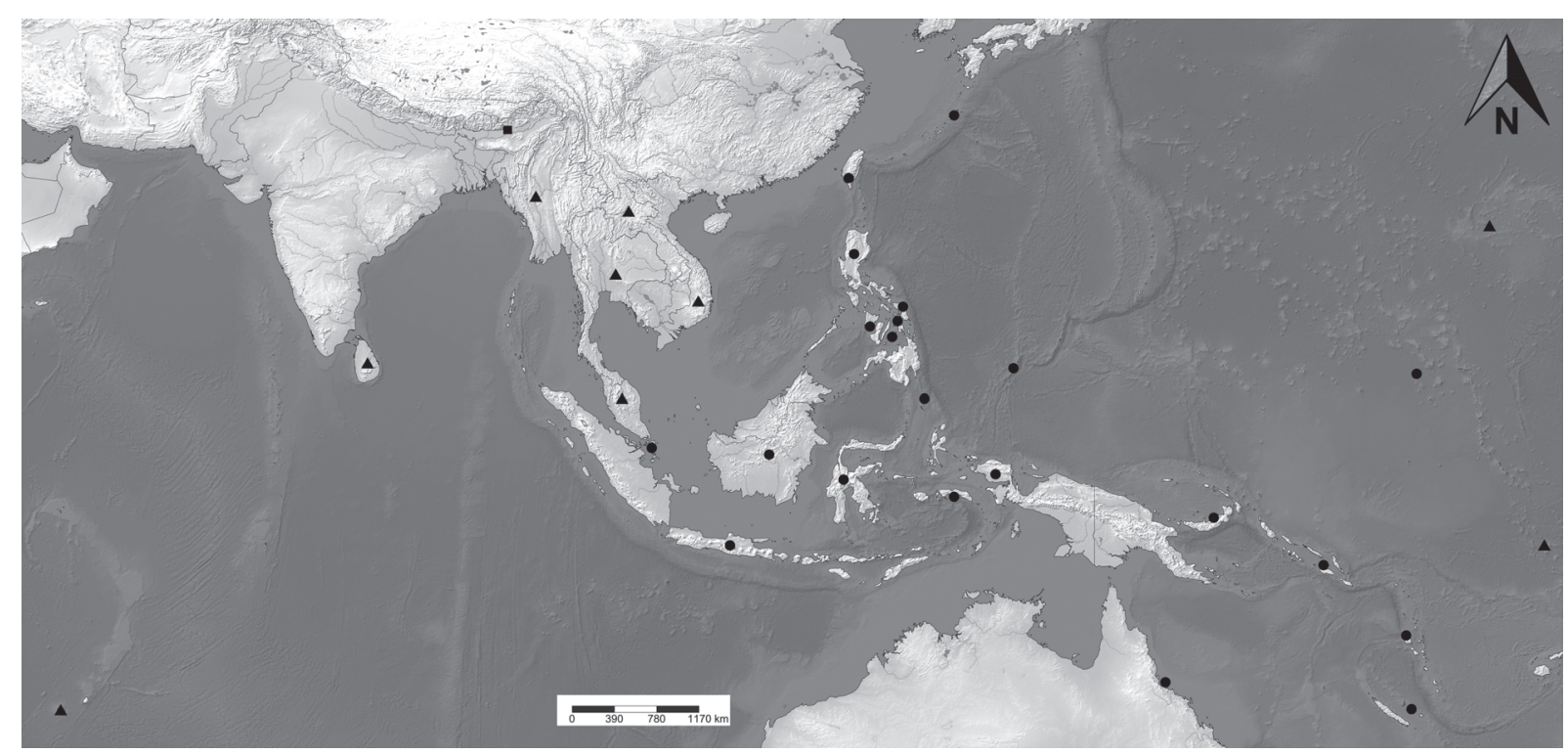

Fig. 2. Distribution map of Strobilanthes reptans (G.Forst.) Moylan ex Y.F.Deng \& J.R.I.Wood: Solid circle (•) indicates native distribution, solid triangle $(\mathbf{\Delta})$ indicates the countries where the species is naturalized, and solid square $(\boldsymbol{\square})$ indicates the currently reported locality. Map created with SimpleMappr (Shorthouse, 2010). 
T.Anderson]. However, the latter is clearly distinct by its prostrate habit, woolly pubescent texture (whole plant densely covered with long white hairs), smaller leaves (up to $2.5 \mathrm{~cm}$ long), sessile and compact inflorescences (Wood, 2001). Whereas, in S. reptans the stem is short and erect, plants not woolly, comparatively larger leaves (up to $6 \mathrm{~cm}$ long), inflorescence lax, usually borne on long peduncles, elongating at maturity.

It is worthwhile to mention here that $S$. reptans is an invasive weed in tropical Indo-Pacific Islands (Meyer \& Lavergne, 2004). It has also apparently escaped from cultivation and has naturalized in Malaysia, Vietnam, Thailand and Laos, and countries neighboring India, i.e. Myanmar, and in Sri Lanka. The corridor of naturalization seems to represent an expansion of the natural distribution range Northeast towards India (Fig. 2). As such, it is likely that the occurrence in India is also the result of a recent naturalization rather than representing a disjunct, natural distribution of the species. However, in India no invasive growth was observed at the site of occurrence or during the cultivation of the plant at the Forest nursery in Tezpur, Assam. Also, the species is restricted to a single locality and the area of occupancy is estimated to be less than 1 sq. $\mathrm{km}$. Therefore, in the current scenario no action needs to be taken to control its spread. As the plant is a little-known ornamental, no history of its cultivation in India could be traced. There is evidence for escape and naturalization as the report here indicates because the plant was encountered in a semi-disturbed area. Hence, further investigation and monitoring of its population is recommended.

\section{Literature Cited}

CHOWDHERY H.J., GIRI G.S., PAL G.D., PARAMANIK A. \& S.K. DAS 2008. Materials for the Flora of Arunachal Pradesh. Volume 2. (Asteraceae
- Ceratophyllaceae). Botanical Survey of India, Kolkata.

HU J., Deng Y.F. \& J.R.I. WOOD 2011. Strobilanthes Blume In: WUZ.Y., RAVEN P.H. \& D.Y. HONG (eds.), Flora of China. Volume 19. (Cucurbitaceae through Valerianaceae, with Annonaceae and Berberidaceae). Science Press, Beijing, and Missouri Botanical Garden Press, St. Louis, pp. 381-429.

KANJILAL U.N., DAS A., KANJILAL P.C. \& R.N. DE 1939. Flora of Assam. Volume 3. (Caprifoliaceae Plantaginaceae). Government of Assam, Shillong.

KARTHIKEYAN S., SANJAPPA M. \& S. MOORTHY 2009. Flowering plants of India, Dicotyledones, Volume 1. (Acanthaceae - Avicenniaceae). Botanical Survey of India, Kolkata.

MEYER J.-Y. \& C. LAVERGNE 2004. Beautés fatales: Acanthaceae species as invasive alien plants on tropical Indo-Pacific Islands. Diversity and Distributions 10: 333347. https://doi.org/10.1111/j.1366-9516.2004.00094.x

MOYLAN E.C., PENNINGTON R.T. \& R.W. SCOTLAND 2002. Taxonomic account of Hemigraphis Nees (Strobilanthinae - Acanthaceae) from the Philippines. Kew Bulletin 57: 769-825.

POWO 2019. Plants of the World Online. Facilitated by the Royal Botanic Gardens, Kew. Available at: http:// www.plantsoftheworldonline.org/ (Accessed on 12.05.2021).

SHORTHOUSE D.P. 2010. SimpleMappr, an online tool to produce publication-quality point maps. Available at: http://www.simplemappr.net (Accessed on 29.08.2020).

THOMAS S., MANI B., BRITTO S.J. \& A.K. PRADEEP 2020. A new species of Strobilanthes (Acanthaceae) from the Western Ghats, India. Taiwania 65(2): 167-171. https://doi.org/10.6165/tai.2020.65.167

VENU P. 2006. Strobilanthes Blume (Acanthaceae) in Peninsular India. Botanical Survey of India. Kolkata.

WOOD J.R.I. 2001. Family 175. Acanthaceae. In: SPRINGATE L.S. (ed.), Flora of Bhutan, including a record of plants from Sikkim and Darjeeling, Volume 2(3). Royal Botanic Garden, Edinburgh and Royal Government of Bhutan. pp. 1243-1293.

WOOD J.R.I. \& R.W. SCOTLAND 2009. New and littleknown species of Strobilanthes (Acanthaceae) from India and South East Asia. Kew Bulletin 64: 3-47. https:// doi.org/10.1007/s12225-009-9098-2 